\title{
THREE CASES OF LARCENY IN WHICH THE ANTI- SOCIAL CONDUCT APPEARED TO REPRESENT \\ AN EFFORT TO COMPENSATE FOR EMOTIONAL REPRESSION.*
}

\author{
By EDITH R. SP̣AULDING, M. D.
}

In the lives of each of the three women whom we are to describe, all of whom were arrested for larceny of various kinds, there is a history of much emotional disturbance, with neither an adequate emotional outlet nor a satisfactory adjustment. Each had experienced over periods varying from 7 to 16 years, an emotional conflict that had been revealed to no one. Associated with much repressed desire, there was in two of the cases a sense of shame, while in the third, there was a disappointment in the materialization of the dreams of childhood. In all three, there was a total ignorance of sex life, and a fear of knowledge regarding it, which resulted in two cases from the sense of guilt that centered about early emotional experiences. One case might be considered subnormal mentally; the other two were classed by Dr. Mabel Fernald of the Laboratory of Social Hygiene as belonging to the superior group of normals; all three showed marked immaturity, either in their efforts to make the minor adjustments of every-day life, or in their conception of adult problems and responsibilities.

CASE 1.-Esther B., aged 23, entered a department store and purchased a pair of scissors, asking the man behind the counter if she might return them if they did not prove to be satisfactory. A few minutes later she cut a hand-bag from a woman's arm. She was soon discovered and arrested. Because of many undetected thefts which had been occurring in the store at the time, the store authorities were anxious to have the case prosecuted.

On looking into her history, the investigator found that the girl had led an exemplary life, had held for some years an office position that entailed considerable responsibility and had also been exceedingly active in church work. As the girl declared that she remembered nothing of what happened after she entered the store, and as the act seemed incompatible with what was known of her past life, it was thought by the court officials that it

* Read at the seventy-fifth annual meeting of the American MedicoPsychological Association, Philadelphia, Pa., June 18-20, I919. 
might be the result of some temporary mental aberration. The girl herself welcomed any attempt to explain what to her was a great mystery and was glad to have us examine her.

During two interviews, the following information was obtained. She was one of three children, her parents were living and there was a very happy home life. When she was seven years old, her sex consciousness was aroused by a man with whom she studied music, while she was sitting at the piano playing her exercises. After a period of hesitation, during which time she went on with the lessons without protest, she asked to have them discontinued. As something derogatory had been learned of the man's reputation, the request was granted without much questioning. At the time, Esther gave no explanation of what had happened. She never talked the matter over with anyone and grew up with a tremendous sense of guilt for which she sought consolation through religion. While constantly saying to herself that she was not to blame, she found solace in songs and sentiments written for the most penitent; such as, "He Threw Out the Life-Line to Me," and "There's a New Name Written Down in Glory, a Sinner Has Come Home." The desire to be saved and to save others had in it an obsessive quality that resulted from the sense of guilt which she felt, but which she was unwilling to admit to herself. This is comparable to the displacement of anxiety expressed so well by Frink * in his description of Stella, a case of anxiety hysteria.

When she was 19, Esther became acquainted with a sailor, who came to her room on one occasion, and tried, she thinks, to assault her. She became unconscious at the time. In talking this over with her, we found that she had no idea what the possibilities of an assault were. She was wholly ignorant of all that relates to reproduction. Although this episode troubled her to some extent, it was insignificant in its influence on her life as compared with the earlier experience.

The emotions that had been aroused in those early years finally found expression in the idea of an emotional union with God. She joined a mission in which revival meetings were common. A year previous to her arrest for the larceny of the bag, she had experienced on Easter Day a religious conversion. At the end of the fourth church service that she had attended during the day, she suddenly began to laugh while being urged to give herself to God. At that moment she felt an electric shock go through her. Her laughter continued all the way home and after she had gone to bed. Suddenly a great calm came upon her and while still awake, she saw eight distinct visions, which she was later able to describe in detail. Following this, she had a feeling of complete union with God with whom she had talked in one of the visions. A year later than this, a short time before she attempted to steal the bag, she had lost the feeling of sympathy with God. Under the strain of unaccustomed responsibility in her position, she was more than ever oppressed by the sense of guilt resulting from her

* Frink, H. W.: Morbid Fears and Compulsions, Moffat, Yard and Company. 
earlier experience, which never really left her except in moments of religious exaltation. She was no longer able to pray; she could not give herself to God.

When she was arrested, she remembered little about what had happened, and slept much of the time for the following three days. At the end of the second day, a member of her family came to her and asked if there was anything he could do. She asked him to pray, thinking that if God would hear his prayer for her then, perhaps on the following day, He would hear her. The next morning she felt that the power of prayer had returned to her, and she believed that she again had God's forgiveness and love. The following verses, as they stand, were written by the patient at this time:

Oh Savior come and help me I need Thee, Oh just now. Come put Thine arm about me And soothe my troubled brow.

The moments seem like hours When burdened down like this, But Savior send Heavenly showers And cover them with bliss.

I know that I have grieved Thee I know that I've done wrong. But right I know I ought to be Condemned-without hope or song.

But Savior Thou hast loved me Thou hast been my constant friend And I know if I come again to Thee Thou wilt love me to the end.

Oh Savior draw me close to Thee Pull every vale aside Until before Thy throne I'll be And there with Thee abide.

I feel that I am with Thee, Lord

Close to Thy bleeding side.

Oh Savior now break every chord

And let me with Thee confide.

Oh Savior can it really be That Thou hast turned Thine ear to me And after hearing my cry, my plea, Hast said, "Child, I have forgiven thee? 
"Yes, but the confidence of an earthly friend

It may take quite some time

But, child, remember to the end

That I'll be always thine.

"And if thou wilt but walk in the light

And let me guide you while going thru'

There will always be in this Christian fight

A work for thee, my child, to do."

Judging from the limited material which we have at our disposal as a result of but two interviews, the following explanation of her conduct seems probable. A child who has displeased her parents and from whom their favor is being withheld may petulantly commit an even worse misdemeanor that perhaps involves personal danger, or may even make a pretense of committing suicide in order to excite their sympathy, regain their favor, and prove their love. To Esther, to cut off and steal a hand-bag was for some unknown reason the most terrible thing she could do. No significant associations with the article could be found. Furthermore, it had no particular value in her eyes and she already possessed a similar one. Still what she had done seemed to her the most horrible thing she could imagine; it was a kind of moral suicide. The whole episode was, we believe, an unconscious attempt to win back favor and to re-establish the emotional relationship with God, which she had previously felt and which to her compensated for her past " $\sin$ " and at the same time furnished her with an outlet for her emotions.

This is comparable to other expressions of emotion that are not infrequently used to end a period of tension and to effect a reconciliation. The following case may serve to illustrate this: A woman who was serving a sentence for larceny in an institution had periods of depression, varying in duration from four to ten days when she ate nothing. During the attack, she was much agitated, frequently saying, "I didn't do it-honestly, I didn't do it." The attack was usually precipitated by some emotional episode in her immediate environment. It almost invariably ended by an emotional explosion such as breaking a pane of glass or throwing her dishes or perhaps even herself on the floor. This emotional explosion appeared to have the effect of a clearing up shower. Her whole attitude of distress and tension then disappeared and she was anxious to eat and continue her work as before. It was later discovered that the first period of starvation had followed the death of an illegitimate child which she was thought to have starved in order that she might not be prevented from returning to her husband and being forgiven by him for her unfaithfulness. Her protestations of innocence during the attack undoubtedly referred to this and the attack itself was probably a repetition of the remorseful period that followed the death of her child. After the attack was over, she manifested as much docility and penitence as a child might after receiving punishment, and shamefacedly promised to be more reasonable in the future. 
Another situation in which complete reconciliation and subordination appear to be sought and in which the masochistic tendency is a little more pronounced is one that occurs not infrequently in reformatories when certain individuals beg for "punishment," threatening the worst possible behavior if it is not granted them. When possible their request is gratified from a therapeutic standpoint and they are allowed to get what to them is an equivalent of punishment in the form of special therapeutic treatment away from the main group, which has become a source of much irritation. Such individuals often show a certain amount of periodicity in their erratic behavior, becoming more and more irritable, perhaps as a result of some constitutional defect, and a series of maladjustments to their environment accumulate which point to a crisis of some kind. Clark $\dagger$ in his studies on epilepsy describes a series of maladjustments that may precede the epileptic attack, which, he believes, is an attempt to compensate for an intolerable environment. Feeling the inevitableness of the approaching crisis, our delinquents attempt to anticipate it by appearing to desire that which they feel will occur as the result of some overwhelming force within them. In this way they maintain a feeling of on-topness and consciously direct themselves to the point of reconciliation which follows either punishment or what to them is an equivalent. This final condition is one in which they revel when they reach it. It represents a climax that is a source of infinite satisfaction and happiness, and is similar to the feeling of reconciliation that Esther had when she was again able to pray.

At the examination, Esther remembered vaguely what had happened in the store. She had been told by others what had occurred and she had difficulty in separating her memory of these accounts from the memory of the actual occurrence. It was found that even before the episode, as a result of the burden of her past life, she was beginning to be self-conscious, to feel that people were noticing what she believed to be peculiarities of her personal appearance, and that they were talking about her. These ideas of reference that were beginning to develop disappeared after the two interviews during which it was possible to give Esther quite a different point of view from that which she had always maintained about the incidents of her early life, and to show her how she could find constructive social outlets for her energy.

There was nothing of consequence found in the physical examination except that the patient was rather poorly developed and nourished. There was no history of epilepsy or evidence of the epileptic personality. A few fainting attacks were described which had usually occurred in crowded subway trains. The family history was negative as far as could be ascertained.

Esther did not graduate from high school because she had failed in the Regents Examinations, but she left school at 19 at the end of the fourth

† Clark, L. Pierce. Clinical Studies in Epilepsy, G. E. Stechert and Company; A further Study of Mental Content in Epilepsy, Psychiatric Bulletin, Oc' ober, 1917. 
year. Later she took a course in stenography, and again left before graduating. For several years, she had held an office position, at 15 dollars a week, as assistant to the supervisor of a number of stenographers. She herself, however, was not required to do stenographic work.

Esther's emotional conceptions appear to have remained on a childish level. The hunger that she displayed in devouring information about things that she should have known years earlier was pitiable and the relief that she felt at unburdening her soul of what she considered her horrible sin was great.

Esther was seen before any sentence was imposed. Although we were unable to demonstrate to the judge the presence of any definite mental abnormality as had perhaps been anticipated, still it was possible to point out the hysterical nature of past symptoms and to show the apparent relationship between the antisocial act and the emotional conflict. Fortunately, the case was dismissed. Had even a suspended sentence been imposed, it would, we feel, have added a burden that could easily have proved too much for one who had been struggling for years with an unnecessary and overpowering sense of guilt. It was hoped that the case would be spared the indictment, but this was not accomplished and a pitiable scene occurred when the girl had her finger prints taken.

So far, in the year that has elapsed since the court episode, our patient has proved the decision of the court to have been a wise one. Freed from the horror of believing that she had committed an almost unpardonable sin, she has had a new lease of life, and by expressing her emotionalism in social ways, she has become more efficient and is mentally more stable. The possibility of a repetition of her antisocial act seems more and more remote.

This case has been an illuminating one as regards the value of examinations in the courts before sentence is imposed. The ease with which the emotional difficulty could be tapped, and the patient's rapid response to treatment, demonstrate the desirability of the court clinic, where such cases should be weeded out before conviction.

CASE II.-Mable C., a woman of 25, was arrested for shoplifting to the extent of thousands of dollars. Her father was a man of culture who was 60 years old when he married her mother, then a woman of 20 , who had much musical ability. Mabel had been educated at private schools of good standing, and had travelled extensively in Europe, as well as in America. After leaving school at 18 , she travelled about with a companion whom her father had chosen for her. The father was obliged to be in the west on a ranch, and she was unwilling to give up the companionship of her friends in order to lead such an isolated life, even though she had planned for years to settle down with him after she finished school. Business reverses had suddenly made her father old, and she no longer regarded him as the fascinating comrade of former years. 
Mabel objected to the companion who disapproved of certain of her friends and considered them frivolous and undesirable, although Mabel now admits that the judgment was correct. She entreated her father by letter to grant her permission to discharge the companion. Her father wished to postpone any change until he should come to her, as he had planned to do within a few months. The tension grew greater and Mabel in her desire for freedom began to annoy her father with frequent night letters on the subject. At this point, she chanced to meet on the street a man whom she knew but slightly, to whom she had been introduced in a distant city some months previously. She accepted an invitation to lunch, and proceeded to pour out her troubles to him as if he had been the wished-for father. As a way out of her difficulties, he suggested that she marry him. The suggestion was followed up by two weeks of strenuous courting and Mabel finally consented, with the proviso, however, that they should not live together as man and wife until she should go to him voluntarily. This seemed to her but fair to her father, to defy whom she was entering the holy bonds of matrimony. Feeling later on, that in her father's eyes her husband would seem an inferior person, she was ashamed of what she had done and saw to it that her husband and father never met in the five years that the latter lived.

The first weeks of the marriage were full of terror for her. Her husband became impatient at what he termed her childishness, never having doubted that a satisfactory adjustment would soon be effected. Any attempt of his to overcome her resistance resulted in unspeakable horror on her part, which grew to such proportions that her knees never failed to tremble in his presence, and like Sue in Thomas Hardy's book, "Jude, the Obscure," who had a similar feeling for her husband, she once nearly jumped from a window to escape him. The following is one of several verses in which she describes her feeling for him:

"Have you ever panted through miserable moments

Waiting for a closed door to open,

A heavy voice to greet you,

Dreaded arms to clutch you in their tenacious grasp

And unclean lips demand a warm salute;

And then sank with an abysmal stupor,

Your tense flesh creeping with loathing,

Your mind whirling with hate,

Your heart a leadened void,

And wondered why in God's name

Your quivering soul lived on?"

It should be said here that her husband was a man who had met with success with many women, several of whom he had married. Although she did not realize it, he was known as a "confidence man," and through cleverness had escaped prison sentences. She believes now that had he been a more æsthetic type, she might have overcome the resistances of her over-sensitive and undeveloped nature, although at the time she felt 
that she was prevented from accepting her husband's affection because of her feeling of loyalty to her father.

With her imaginative nature, she had always looked forward to marriage and all that it meant to her-a home and children-both according to story book ideals, requiring no care and causing no pain, and the affectionate companionship of her husband, fathering her always. This latter attitude was so obvious that her husband had said that her relationship to him was that of a child rather than of a wife. Adler $\ddagger$ says in his description of neurotically retained childhood defects, “. . . . the fact very frequently comes to light that the patient is very enthusiastic for life, for work, for love and marriage, but platonically, while secretly he bars the access to them through the neurosis, in order to make sure of his domination in the more limited field of the family with the father and mother."

After some emotional episodes with her husband that filled her with terror, Mabel felt that it would never be possible for them to have children. She, therefore, visited an orphan asylum and made all arrangements for the adoption of a child before consulting her husband. When he was told of her plan, he was vehemently opposed to it, which was natural enough at that time. About the same time, and still during the first months of her married life, a Russian wolfhound to which she was devoted died, partly as she thought from the results of her husband's maltreatment.

The first shoplifting occurred after these two incidents, and continued at varying intervals for the next seven years. After what were to her six years of torture with her husband, she left him. During the succeeding year, she rapidly spent what money she had with a childishness which was characteristic, in spite of knowing that there was no prospect of more from the same source. She attempted with little success, to become a moving picture actress, and had finally exhausted her funds when she was arrested for taking a number of things from department stores, which were finally traced by the store detectives. She seldom used the stolen articles, usually clothes, she rarely gave them away, and she never sold them, no matter how great their accumulation became.

This case, which has had a fairly exhaustive analysis may be classified as a compulsion neurosis. The mental conflict centering about her unadjusted marital relationship was the immediate cause of her antisocial conduct, which more fundamentally represented an effort to gain satisfaction in the expression of her ego by successfully defying authority in the form of the law, as a result of resistance to parental authority as expressed by her father and her husband. This type of compensation is similar to that described by Clark $\S$ in cases in which the stealing was the result of antagonism to the father and represented a desire for childish revenge. The

$\ddagger$ Adler, Alfred : The Neurotic Constitution, Moffat, Yard and Company. P. 96 .

$\$$ Clark, L. Pierce: A Psychologic Study of Stealing in Juvenile Delinquency, Archives of Neurology and Psychiatry, Vol. I, pp. 535-546, May, 1919. 
antisocial behavior ceased in Clark's cases when a satisfactory adaptation to parental authority was made.

Mabel now realizes that even as a child she had been conscious that she could get anything she wished from her father. She had ruled him absolutely. It was only when the change came which followed his business reverses that she suddenly lost her power over him. His sudden attempt to exert parental authority was intolerable to her. She wanted to be humored and to rule, true to the picture of the neurotic constitution that Adler I so well describes. As her father had failed her, she tried to find a substitute, some one who would humor her and whom she could rule in the same way in which she had always ruled him. This man who suggested that she marry him seemed a possible candidate, in other words, a second father. Judging by his courtship attitude, she felt that he would fill such a need. Acting on this estimate of him, she made the stipulation regarding their marital relationship. But after their marriage, her authority again failed. He was unwilling to submit to her will and would not allow her to adopt the child that she longed for, and he tried to insist on a normal relationship between them. This then was the immediate cause of her clash with his authority-her inability to obtain by adoption the child that she desired, and to make the adjustment that would have given her in a natural way what she most desired, children and the intimacy of a home. She never dared to venture living in an apartment, fearing the enforced intimacy of her husband, but lived always in hotels, maneuvering to find excuses to absent herself from him as much as possible, in the intervals between his business trips.

The unexpected emotion that was shown when children were mentioned and the frequency of the child and of the child's cry in her dreams, all contributed to increase the significance of the maternal longings in a woman too immature and inhibited by what she considered loyalty to her father to make the necessary marital adjustments. In one of her dreams, she attempted to escape the horror of hearing the cry which called and which she could not reach, by running away from it, and her sense of satisfaction came to her by defying authority in the form of the law as she ran.

Mabel's immaturity was largely due to her extreme attachment to her father which resulted in part, at least, from his discouragement of friendships with those of her own age. Once during her adolescent years, she innocently sent a picture to a youth of her own age. Her father learned of it and made a scene, asking many questions about her customs and those of her girl friends. He forbade the repetition of such a reprehensible thing as exchanging photographs, and discouraged even innocent correspondence. Rebuffs such as this appeared to be sufficient to keep her from forming outside friendships, particularly with the opposite sex and made her content herself the more with her father's companionship.

I Adler, Alfred: The Neurotic Constitution, Moffat, Yard and Company, 1917. 
The reason that her defiance to authority took the form of shoplifting may perhaps be found in the fact that her first misunderstanding with her father occurred when as a child she had taken some stamps from him, an act which he interpreted as stealing but which she felt was within her rights. She had always assumed the right of appropriating anything that was his. She had frequently taken for her own use the appointments on his desk and personal belongings from his room, things which it gave her pleasure to have near her. At no time, however, had she appropriated anything in the same way which belonged to her mother. She never forgave her father for not understanding her point of view regarding the incident of the stealing, for his harsh scolding and particularly for telling her mother. In other words, this event represented her first collision with authority in which she had failed to dominate. She believes that she was never able after this episode to express her affection for him as she had done previously. Her father often remarked about the change, and said he longed for a fairy wand that would make her the affectionate child that she had been before.

During one winter in the seven years of her married life, she was interested in the activities of a man, considerably older than herself, who lived in the same hotel but whom she knew only slightly. He was active in social reforms. She enjoyed being of assistance to his secretary at times, although this was unknown to him. During this period of interest. there was no larceny. She begged her husband at the time to allow her to take a secretarial course but this was denied her. If some such utilization of her energy had then been possible, it would probably have provided a substitute which would have prevented further antisocial conduct. In this interest there was also a strong association with the interests of her father who had been a literary man.

Writing has a creative element that frequently furnishes a fairly satisfactory sublimation of maternal and paternal instincts. If the husband had ceased to insist upon a normal relationship and if she could have had a creative outlet through writing, she would probably have fulfilled her childish ideals without the adoption of a child, and the antisocal conduct would not have been indulged in. She herself said that she felt she would not have stolen had she lived on with her father or had she been happily married.

During her sojourn in our hospital, \| she became one of our most reliable and efficient workers. Although at first she was unable to thread a needle or do anything of a practical nature, she learned to sew and made many artistic things in the occupational room. She later advanced to the kitchen, where she became a good cook and almost a housekeeper; she could never express enough appreciation for her kitchen experiences. All this time, through the courtesy of one of the laboratory staff, she was studying type-

|| The Psychopathic Hospital of the Laboratory of Social Hygiene in connection with the New York State Reformatory for Women at Bedford Hills, N. Y. 
writing and stenography in which she made good progress. She tried her hand at short-story writing in the hope of earning money to pay her debts, and later began to write verses, which, though not indicative of great literary talent, were invaluable in revealing her mental life and showing the progress of the analysis.

When it was necessary to discontinue our study of her, she was able to return to the main institutional group, where she made contacts of various sorts with other women, which were much to her credit. She became also of considerable help to the third patient whom we are to describe. After leaving the institution, she took an office position. She is at present taking a secretarial course two evenings a week, and is rapidly becoming more proficient in stenography and typewriting, as well as in library work, which she enjoys, partly because of early associations with her father, and partly because of what is probably an innate interest in books. In her dreams, books and libraries occurred frequently and were apparently a source of much satisfaction to her. The satisfaction gained through similar work even though there was little of it during the winter previously mentioned when she was not tempted to steal is additional evidence of the wisdom of this choice of literary occupation.

It may be of interest to add that this patient feels that her life would never have amounted to much had it not been for her institutional experience and she believes that in no other way could she have attained the development and mental rebirth which she believes resulted from it. It has sometimes seemed as though she had unconsciously desired the prison experience and sought the reformatory as a way out of her difficulties in the same way that the war neurosis sought the hospital to escape the trenches. She said herself that she felt that only by going to an institution would she be able to escape her husband.

In this case it was possible to reach the deeper emotional levels only after many months. Much time elapsed before complete confidence was gained and superficial resistances overcome. There was sufficient time, however, for a satisfactory reconstruction before the patient left the hospital. When cases of this kind that are capable of re-education come to our reformatories, it is a pity not to be able to give them the opportunities that are needed to effect their reconstruction.

CASE III.-Harriet U., aged 24, was sentenced to the reformatory on the charge of petit larceny. Following some incorrigibility and petty stealing for which she had been given probation in the past, she was finally arrested for stealing a hat valued at five dollars from a department store, for which she was given a three-years' indeterminate sentence.

Because of her erratic behavior before entering the institution in staying away from home, lying, stealing, and being generally unmanageable, and because in the institution she had great difficulty in adapting herself to the 
regulations and acted with a childishness that seemed incompatible with her good mentality and general appearance of womanliness and poise, she was transferred to our hospital for special study and treatment. The struggle which Harriet went through in her effort to coöperate with us and help us to find the cause of her emotional resistance was pitiful. On the one hand, was her desire to talk about the tangle of her life and face her difficulties in order to make good, and prove her affection for those who were trying to help her; on the other hand as deterring factors were the sense of shame for her past, the dread of admitting her guilt, and the fear of incriminating another person whom she loved.

After this struggle had continued for several months and when it was too late to continue the treatment further, the following history was disclosed just before she left the hospital. Her father, who was said to have been alcoholic and a ne'er-do-well, had married her mother after she had converted him to Catholicism. Harriet believed that her mother married him because of her pride in his conversion rather than for real love of him. Later, when he lost interest in the church, and did little toward the family's support, the wife's ardor cooled and she would have separated from him had it not been for Harriet's passionate affection for him. At a time when he was not living with the family during Harriet's childhood, he used to come to the house to see his daughter. She would cling to him and refuse to let him go, making such a disturbance that it was difficult for him to get away.

It was in her relationship with her father (she is apparently not clear in her own mind as to what actually happened) that her sex consciousness was aroused, which resulted in the most profound sense of guilt regarding their relationship. This dated from her seventh year. From that time on, Harriet could not bring herself to talk of it to anyone because she feared to incriminate him. Her sense of guilt made her shun everything of a sex nature to such an extent that she was wholly ignorant of the simplest physiology; even an enema was to her a form of assault. She could not submit to it. Her dread extended to a variety of physical things. Atropine dropped into her eyes caused an intense emotional reaction. She could with the greatest difficulty submit to dental treatment even when it did not cause pain.

For years she had avoided expression of affection in every form because of the sense of shame that was connected with expression of affection in her childhood. As a result of this, even the most desirable of suitors had been kept at a distance. She knew that a certain man wanted to tell her how much he cared for her and ask her to marry him, but she could not bear to have him do so. When he urged her to spend the evening at home so that they might talk, she insisted upon going out to the movies or to a dance. She preferred anything that would prevent him from touching her deep repressed emotions. After she had brought herself to talk with us about her early life, her attitude toward the question of marriage changed and she felt that should another such situation occur in her life, she would no longer dread it, but would be able to allow the real affection that she felt to come to the 
surface. The nearest approach to a direct expression of her feelings had been in competitive dancing, which she loved, but which she could never talk about because she associated it with the forbidden regions of her emotional life and was consequently ashamed of it.

As she looked back on her life, it seemed a series of might-have-beens and feelings of remorse. She felt that she had only appreciated situations when it was too late to remedy them. Her mother died when Harriet was I7 or 18 years old, a year after the father's death, and Harriet had never ceased to grieve actively for her mother. On studying into the nature of this grief that had persisted obsessively for six years, it was found that it was not so much sorrow for her mother's death, because her mother had suffered greatly during her life, and was glad when the release came, but it was a sense of remorse at the unhappiness she had caused her mother by her extreme affection for her father, a condition which she recognized only when it was too late to make up for it in any way. Her aunt had pointed out to her that she had been the source of much unhappiness to her mother, for had it not been for her affection for her father, her parents would have separated permanently, and this would have relieved her mother of much sorrow. The intensity of Harriet's sense of remorse about her mother was caused by her feeling of guilt connected with her relationship with her father.

It was always when she was worrying intensely about her mother and longing for her that she stole. She remembered that in the past she had been in the habit of stealing from her mother although this was never discovered. She never stole, however, from her father. She thought that in some way the cause of her stealing lay in the sense of guilt that had caused her to deny her deeper emotions and her longing for affection any normal outlets. She felt the connection but she could not explain it. It was as though the stealing were a vicarious expression of her repressed emotion; it might be termed an illusion of compensation. Much of her antisocial conduct that expressed itself by defying lier aunt, with whom she lived, and either refusing to tell where she had been (although what she had been doing had been quite innocent) or lying about it, were all attempts to protect the inner turmoil of her life from the interference of outsiders.

Harriet asked with a great deal of emotion if the early experience had really been so terrible as she had always supposed. It had seemed to her so unfair to tell, or even to intimate this thing about her own father. She was tremendously relieved to be told that she was too young at the time to be held responsible and that one could hardly blame the father for what had happened since so little was known of him and of the general situation. This simple reassurance relieved her of the intolerable feeling of oppression from which she suffered for a period of 14 years, and she felt that now she could unearth the emotion she had been repressing with such tragic results and learn to express it in her every-day life by projecting her interest into the lives of those with whom she came in contact. In this way she could learn in time to direct her energy along constructive 
lines away from herself. In the past it had taken the path that turned inward and had ended against an impassable wall that shattered it as an entity and a constructive element, and forced a part of it, at least, to seek by-paths that constituted her illusion of compensation.

With this patient, many months were consumed in simply approaching the conscious emotional experiences of childhood. In spite of the greatest effort at coöperation and sincere protestation of confidence on her part, it was impossible for her to overcome her resistances until it was too late for us to accomplish anything with her in the way of reëducation. The conflict that she went through before leaving the hospital was intensified as she remembered that if she could not bring herself to talk, she would have one more regret to add to the already long list of might-have-beens. The thought was almost more than she could bear.

Although she gained a temporary relief from the point of view that it was possible to give her at that time, there was still so much readjustment required in her life, on the basis of the new foundation, that it is not strange that without further individual treatment the process of reconstruction did not continue long without regressions. Although she responded well at first to her new environment, after a while she lapsed into the old habits of antisocial behavior and as a result lost for a time, at least, all signs of ambition. She stole and lied to such an extent that it was necessary to remove her from the position of responsibility which had been given her. Furthermore, she formed a strongly emotional and undesirable attachment for a young woman who had kept a house of ill-fame. Harriet had never been sexually delinquent although there had been much opportunity and she had spent many nights sleeping in hall-ways. The experiences of her seventh year were a safeguard against this, as well as being the apparent cause of her many difficulties.

Recently, due perhaps to a brief continuation of the former analysis, Harriet has made a fresh start with a renewal of courage which she seemed to have lost in consequence of her inability to take advantage of the opportunities that were offered her. She need not have been discouraged, however, as her life habits were too deeply rooted to be dislodged in so short a time. Still much relief has already been obtained by having some light thrown on the "horrors" of her past and as difficult as her readjustment will be, it can hardly cause her as much suffering as resulted from the intense feelings of remorse that were associated with the memory of her early experiences. We believe that a satisfactory adjustment of her life should, under suitable treatment, be wholly possible.

This case is similar to those described by Healy ** in which the stealing was the result of a mental conflict. There is no evidence in our case, however, that the knowledge of sex and of stealing

** Healy, William. Mental Conflicts and Misconduct. Little, Brown $\&$ Co. 
were acquired at the same time to account for their close relationship.

Harriet's case resembles that of Mabel in the compulsive nature of the stealing, which in each instance apparently resulted from a conflict of emotions. In Mabel's case, the conflict arose directly from a genuine situation which was going on at the time, although it was based on developmental conditions of a much earlier period, her injudicious training. In the last case, however, there was no actual situation in the present that was intolerable. Her conflict lay in the obsessive thoughts that were based on actual situations in the past, her experiences with her father. The first case cited also revealed this latter condition and her conflict resulted from obsessive ideas regarding a past situation, her experiences with her teacher, rather than a situation that was intolerable at the time.

In the last two cases no physical condition was found that would have a bearing on the antisocial conduct. Both are welldeveloped and well-nourished individuals. Moreover, their intellectual capacity, as has already been stated, is well above the average.

\section{SUMMARY}

The three cases represent, we believe, attempts to compensate for emotional repression, which has been associated with a distressing mental conflict.

In the first case, there was an internal fermentation, which bubbled over in an antisocial way when the patient, because of unusual strain in her environment that made her past more oppressive than usual, was unable to obtain an emotional outlet and a feeling of compensation through her religion. Had it not been for her mental conflict during sixteen years, she would not, we believe, have become delinquent in the eyes of the law. There seems little probability now of her delinquency being repeated. That she chose the outlet she did instead of others apparently resulted from the fact that this particular act typified to her the worst thing she could do and represented an attempt to win back favor and effect a reconciliation. The sex avenues were blocked on account of her fear and sense of shame. No associations could be ascertained in our brief study to explain why the stealing 
of a hand-bag was to her such a terrible thing. Some more definite relationship, however, may be revealed later on. The interesting characteristic of this case was her ready accessibility and her quick response to treatment. Those who have worked and struggled with delinquents of the institutional type will appreciate finding a patient with whom so much could be accomplished in two interviews.

In the second case, the actual conflict centered about her married life, that is, her difficulty in adjusting herself to marital conditions and her inability to obtain children by adoption. The reason for suddenly making the decision that launched her into the predicament of her marriage was a conflict with the authority of her father, which resulted largely from the unwise training that had allowed her almost supreme mastery during her childhood and from her excessive dependency on him. When at the age of eighteen, she suddenly felt her father forcibly exercising his authority, the situation was intolerable to her and she took the quickest way out, regardless of consequences. Her inability to become eventually reconciled to her husband resulted partly from her dream world habits, which had prevented her from making satisfactory contacts with reality, and partly from rebuffs that her emotions had had at various times in her development that prevented them from seeking expression in an adult way and that repressed them to a lower level in a filial relationship with her father which had become wholly satisfying to her up to the time of his business reverses and with which she had made up her mind to content herself throughout her whole life.

In the third case, as in the first, emotions had been aroused at an early age in a way in which there was such a strong association of shame that everything even remotely connected with the sexual sphere had in consequence been repressed. The energy that had been repressed as a result of the conflict had expressed itself asocially in several ways, one of which was stealing. The outlets that she chose seemed to furnish her in some way with what we have called an illusion of compensation. Whether or not the early stealing from the mother was a factor in directing the energy that was seeking vicarious outlet, it was not possible to determine in the limited time remaining after the conscious emotional levels were reached. The future analysis of the case should be full of interest. 
In all three cases, had the mental life been accessible to wise guidance at an earlier period, the antisocial behavior might easily have been prevented. While the court clinic and the institution laboratory can do much to reconstruct the re-educable delinquent, the real opportunity for constructive work is in the community where a knowledge of the principles of mental hygiene can be spread abroad through the education of the public en masse and through individual contact so that, among other things, mental conflicts and social maladjustments may be recognized and treated before they cause antisocial conduct and mental abnormalities. 